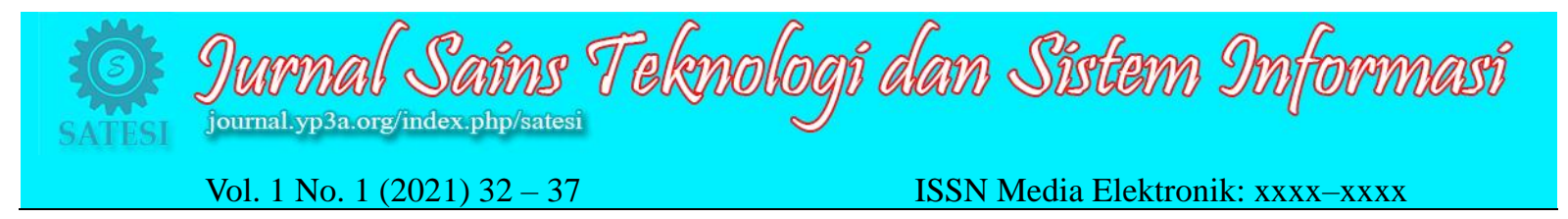

\title{
Prototype Stabilitas Kadar Air Garam Berbasis Arduino Uno (Studi Kasus : Desa Batang Kilat Medan)
}

\author{
Jamaludin $^{1^{*}}$, Josep Estrada Bangun ${ }^{2}$ \\ ${ }^{1,2}$ Teknik Informatika, Politeknik Ganesha Medan, Medan, Indonesia

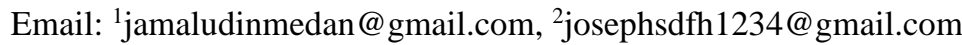

\begin{abstract}
The salt content in pond water is one of the main factors in shrimp farming. Changes in the salt content (salinity) of water is a classic problem for shrimp farmers, because it can cause losses due to the death of shrimp resulting in crop failure. This study aims to design a prototype that functions to stabilize the salt water content in ponds, so as to prevent shrimp death. This prototype design technique is based on Arduino Uno and uses the conductivity determination method. Determination of conductivity is done by measuring the voltage. Voltage measurement is done by flowing a current with a voltage of 5 volts through an electrode that is inserted into the water. The potential difference between the ends of the electrodes is measured as the sensor input voltage. The results showed that this prototype can stabilize the salt content when the salt content in the container is unstable due to the addition of fresh water or salt water. It is hoped that this prototype can be applied to pond cultivators so that it can be useful for preventing shrimp death.
\end{abstract}

Keywords: Prototype, Salinity, Conductivity, Arduino Uno.

\begin{abstract}
ABSTRAK
Kadar garam dalam air tambak merupakan salah satu faktor yang utama terhadap perkembangbiakan udang. Perubahan kadar garam (salinitas) air menjadi persoalan klasik bagi petani tambak udang, karena dapat menyebabkan kerugian akibat kematian udang sehingga gagal panen. Penelitian ini bertujuan untuk merancang sebuah prototype yang berfungsi untuk menstabilkan kadar air garam pada tambak, sehingga bisa mencegah kematian udang. Teknik perancangan prototype ini berbasis Arduino Uno dan menggunakan metode penentuan konduktivitas. Penentuan konduktivitas dilakukan dengan cara mengukur tegangannya. Pengukuran tegangan dilakukan dengan cara mengalirkan arus dengan tegangan 5 volt melalui elektroda yang dimasukkan ke dalam air. Beda potensial antara ujung-ujung elektroda diukur sebagai tegangan masukan sensor. Hasil dari penelitian yang dilakukan menunjukkan bahwa prototype ini bisa menstabilkan kadar garam ketika kadar garam pada wadah tidak stabil karena penambahan air tawar atau air garam. Harapannya prototype ini bisa diterapkan pada petani tambak sehingga bisa bermanfaat untuk mencegah kematian udang.
\end{abstract}

Kata Kunci: Prototype, Salinitas, Konduktivitas, Arduino Uno.

\section{Pendahuluan}

Budidaya tambak merupakan industri akuakultur terbesar di Indonesia yang diindikasikan dengan kontribusi paling besar terhadap nilai produksi total Budidaya udang di wilayah Indonesia telah menjadi

akuakultur. Indonesia memiliki potensi lahan budidaya bahan kajian para peneliti, antara lain :

tambak yang mencapai luas 2,96 juta hektar dengan pemanfaatan lahan budidaya tambak seluas 0,65 juta hektar yang berarti ada peluang pengembangan budidaya tambak seluas 2,31 juta hektar. Saat ini teknologi pembesaran udang windu (Penaeus Monodon) dan udang vaname (Litopenaeus Vannamei) telah berkembang cukup pesat mulai dari teknologi sederhana, semi intensif, intensif, dan super intensif, kualitas air harus dipertahankan pada kisaran optimum kebutuhan biota budidaya.[1]

Penelitian yang bersumber dari jurnal, ditulis oleh Nuzlya Ramadhan, dkk dengan judul : "Rancang Bangun Sistem Monitoring Konsentrasi Kadar Garam Pada Tambak Ikan Bandeng Menggunakan Android”. Dalam penelitian tersebut dijelaskan bahwa hasil penelitian menunjukkan bahwa hasil perancangan

Diterima Redaksi: 09-09-2021 | Selesai Revisi: 09-09-2021 | Diterbitkan Online: 10-09-2021 
sistem monitoring konsentrasi kadar garam pada curah hujan yang cukup tinggi menurunkan kadar tambak ikan bandeng yang sudah dilakukan garam sehingga menyebabkan kematian udang.[5] menggunakan Arduino Uno, sensor konduktivitas, sensor $\mathrm{pH}$, sensor suhu, modul wifi, Mi-Fi dan Smartphone untuk mengakses aplikasi android. Hasil pengujian fungsionalitas Mikrokontroler yang telah dibuat sesuai dengan perancangan dan berjalan dengan baik. Sistem yang dirancang dapat mengirimkan informasi berupa nilai kadar garam, sensor $\mathrm{pH}$, sensor suhu dan nilai TDS dengan akurasi sensor yang sudah linier dengan hasil pengukuran menggunakan alat ukur konvensional dengan nilai error tertinggi masingmasing sebesar $1.3 \%, 2.06 \%, 0.702 \%$ dan $1.5 \%$. Kesimpulan dari penelitian tersebut adalah Sistem monitoring dapat digunakan untuk pembacaan sensor dan memproses data sensor. Sistem yang dirancang dapat mengirimkan informasi berupa nilai kadar garam, sensor $\mathrm{pH}$, sensor suhu dan nilai TDS dengan akurasi sensor yang sudah linier dengan hasil pengukuran menggunakan alat ukur konvensional dengan nilai error tertinggi masing-masing sebesar $1.3 \%, 2.06 \%, 0.702 \%$ dan $1.5 \%$.[2]

Perubahan kadar garam dalam air tidak bisa diketahui, kecuali para petani harus turun ke tambak dan melihat kondisi udang sudah mulai 'mabuk' dan akhirnya mati, ini sangat menyulitkan apabila perubahan kadar garam yang drastis pada saat malam hari. Dengan kondisi inilah, perlu dirancang sebuah perangkat untuk mendeteksi tingkat kadar garam dan secara otomatis akan menggerakkan suplai air tawar atau air garam yang dapat menetralkan kadar garam, sehingga dapat mengurangi tingkat kematian udang.

\section{Metode Penelitian}

\subsection{Teknik Pengumpulan Data}

Teknik pengumpulan data yang dilakukan dalam penelitian ini adalah[6]

\section{a) Observasi,}

Kegiatan mengamati langsung terhadap kegiatan yang sedang terjadi di lokasi penelitian, untuk mendapatkan Penelitian bersumber dari buku yang ditulis oleh Dwi data-data yang lengkap dan akurat. Pada metode Ratna Nurhajarini, dkk yang membahas tentang faktor observasi ini peneliti melakukan pengamatan langsung pendukung peningkatan jumlah produksi dalam usaha ke lokasi tambak yang terletak di desa Batang Kilat budidaya adalah tenaga kerja, luas tambak dan jenis Medan untuk memperoleh kondisi yang sebenarnya.

pakan. Fungsi-fungsi manajemen (perencanaan, organisasi, pelaksanaan dan pengawasan) sangat berpengaruh terhadap pengelolaan usaha budidaya udang. Peningkatan produksi tidak lepas dari manajemen yang baik dalam pengelolaannya semakin lemah penerapan fungsi-fungsi manajemen, produksi semakin rendah, sebaliknya semakin baik penerapan fungsi-fungsi manajemen produksi semakin tinggi. [3]

Penelitian tersebut bisa diimplementasikan untuk budidaya tambak yang sudah menerapkan teknologi semi intensif, intensif, dan super intensif. Namun sangat berbeda dengan kasus yang terjadi di Desa Batang Kilat Medan yang masih menggunakan cara tradisional dengan teknologi yang sangat sederhana dan menerapkan secara turun temurun . Keberhasilan dalam mengembangkan budidaya udang hanya bersandar dengan faktor alam saja. Ketika mereka gagal panen saat ini, mereka coba bangkit kembali dan terus mencoba dan berhasil kemudian gagal lagi dan keadaan itu terjadi hingga saat ini.[4]

Banyak faktor yang menentukan tingkat keberhasilan tambak udang, salah satunya adalah tingkat kadar garam dalam air (salinitas). Salinitas berpengaruh langsung pada air tambak terkait dengan toleransi air tambak terhadap derasnya curah hujan yang dapat menyebabkan air tambak tidak normal. Biasanya tingkat kegagalan panen cukup tinggi adalah saat pasang mati ditambah curah hujan yang cukup tinggi sehingga air laut tidak bisa masuk ke tambak, dengan

b) Wawancara,

Kegiatan ini dilakukan dengan berkomunikasi secara langsung, dan melakukan tanya jawab kepada warga yang petani tambak di lokasi guna memperoleh informasi yang lengkap.

c) Studi Pustaka,

Metode ini membantu penulis dalam hal membuat laporan yang ditunjang dengan buku-buku, jurnal, internet dan referensi yang berhubungan dengan masalah yang sedang diteliti.

\subsection{Teknik Pelaksanaan Penelitian}

Metode yang digunakan dalam penelitian ini, yaitu survei lapangan, perancangan dan pembuatan alat, pengujian alat, pengujian alat dan penyusunan laporan akhir kegiatan, seperti tertera pada gambar 1

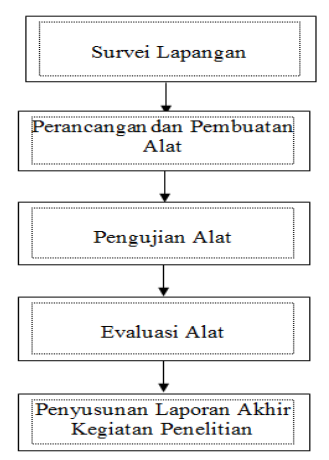

Gambar 1. Diagram Skema Pelaksanaan Penelitian

DOI: $\mathrm{xxxx}$

Lisensi: Creative Commons Attribution 4.0 International (CC BY 4.0) 


\section{a) Survey Lapangan}

Pada tahap ini diharapkan akan mendapatkan sebuah data secara langsung dan akurat tentang permasalahan tambak udang di masyarakat, dalam ini peneliti berhasil mewawancarai penduduk Desa Batang Kilat Kelurahan Sei Mati Kecamatan Medan Labuhan Kota Medan bertempat tinggal tidak jauh dari pantai.

\section{b). Perancangan dan Pembuatan Alat}

Pada tahap ini dilakukan perancangan prototype pendeteksi kadar garam, adapun rangkaian skema elektronika dari alat pendeteksi kadar garam dapat dilihat pada gambar 2 .

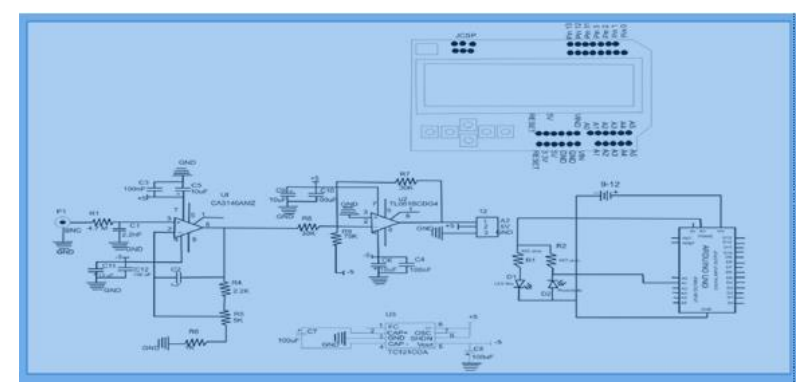

Gambar 2. Rangkaian skema elektronika prototype

Gambar 2 di atas merupakan skema rangkaian elektronika dari sensor kadar garam dan LCD. Pada rangkaian elektronika sensor kadar garam dapat dilihat bahwa setelah dari konektor sensor kadar garam tegangan akan mendapatkan penguatan dari Op-Amp CA3140 sehingga membutuhkan catu daya simetris $5 \mathrm{~V}$ GND dan $+5 \mathrm{~V}$. Prinsip kerja rangkaian elektronika sensor kadar garam adalah terdiri dari rangkaian low pass filter dengan menggunakan komponen resistor 4,7 MOhm dan capacitor $2,2 \mathrm{nF}$ yang berfungsi untuk meloloskan sinyal dibawah frekuensi cut offnya. Untuk aktif low pass filter pada rangkaian selanjutnya menggunakan komponen resistor variabel $100 \mathrm{~K}$ dan capacitor $1 \mathrm{uF}$. Saat Resistor Variabel $100 \mathrm{~K}$ diatur maksimal, maka akan terjadi penguatan sebesar 101 kali. Sedangkan pada rangkaian elektronika sensor kadar garam,keluaran photodioda langsung dikirim pada pin A1 pada bagian analog input papan arduino uno tanpa menggunakan penguatan dikarenakan arduino dapat membaca analog input yang nilainya lemah sekalipun. Setelah itu data yang diterima oleh arduino diproses sesuai dengan program yang dibuat oleh penulis kemudian akan dikirim dengan pin D4, D5, D6, D7, D8 dan D9 yang terhubung dengan LCD kemudian hasilnya ditampilkan pada LCD. Dalam rangkaian elektronika ini baik sensor dan LCD menggunakan tegangan input $5 \mathrm{~V}$ yang diperoleh dari Vout papan Arduino Uno yaitu pin 5V.

Flowchart proses sistem pengendalian salinitas ditunjukkan pada gambar 3 .

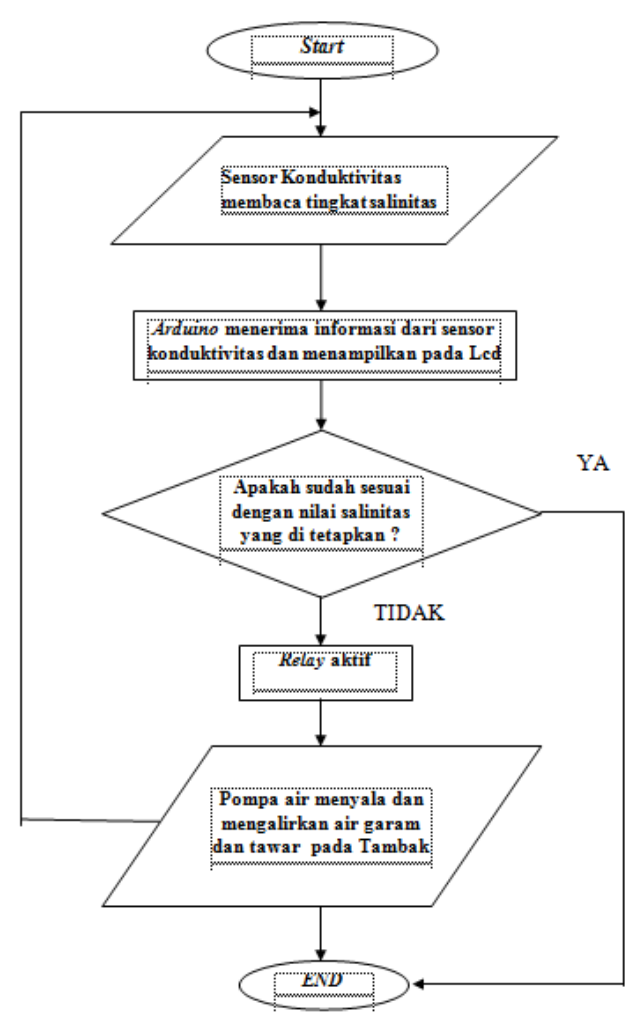

Gambar 3. Flowchart sistem pengendalian salinitas

Pada Gambar 3 dapat dijelaskan bahwa prinsip kerja dari sistem ini adalah setelah sensor konduktivitas mendeteksi tingkat salinitas pada air, maka selanjutnya arduino uno akan menerima informasi tingkat salinitas pada air tersebut. Informasi tingkat salinitas yang didapat akan ditampilkan pada LCD 16x2. Lalu apabila informasi tingkat salinitas yang diterima memenuhi nilai yang telah ditetapkan, maka tidak akan ada tindakan yang dilakukan oleh sistem ini. Namun ketika tingkat salinitas terdeteksi lebih tinggi dari nilai yang telah ditetapkan, maka Arduino Uno secara otomatis memerintahkan relay untuk aktif. Akibat dari relay yang aktif ini, maka pompa air listrik yang terhubung dengan relay dapat menyala dan mengalirkan air tawar atau garam. Air yang dialirkan ini bertujuan untuk membuat tingkat salinitas pada air stabil. Relay ini akan terus aktif hingga sensor konduktivitas mendeteksi tingkat salinitas air tersebut sudah sesuai dengan nilai yang sudah ditetapkan. Apabila tingkat salinitas sudah sesuai dengan nilai yang telah ditetapkan, maka secara otomatis arduino uno akan memerintahkan relay untuk tidak aktif sehingga pompa air akan berhenti bekerja.

Kemudian dilakukan perancangan mekanik prototype seperti gambar 4 .

DOI: $\mathrm{xxxx}$

Lisensi: Creative Commons Attribution 4.0 International (CC BY 4.0) 


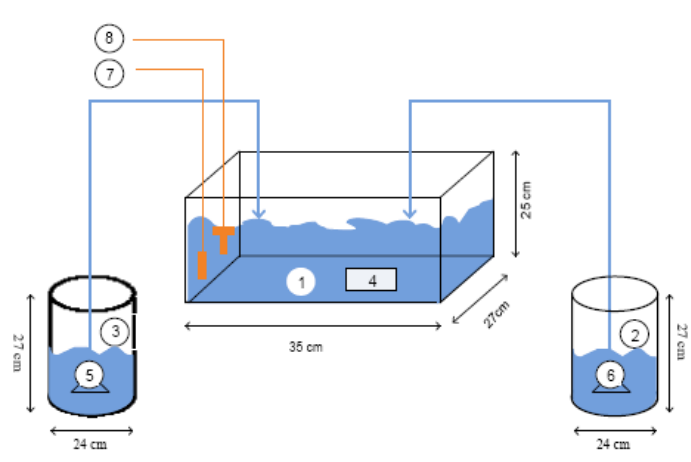

Gambar 4. Perancangan mekanik prototype

Kemudian perancangan teknologi yang akan diterapkan bisa dilihat pada gambar 5 .

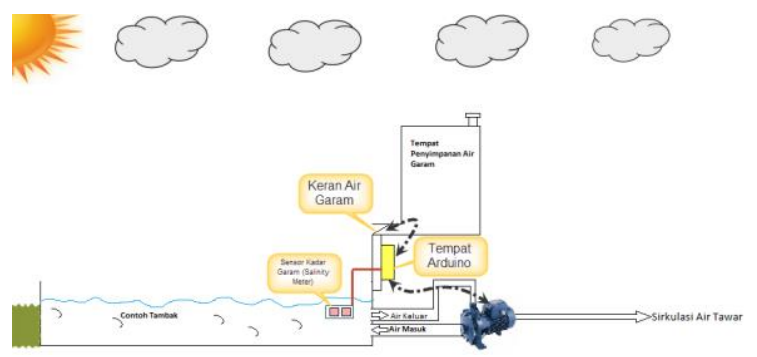

Gambar 5. Perancangan teknologi yang akan diterapkan

\section{c) Pengujian Alat}

Sebelum alat ini diaplikasikan, dilakukan pengujian dengan beberapa sampel terlebih dahulu, tujuannya untuk memastikan alat yang kami buat dapat berfungsi sesuai konsep yang telah dirancang

\section{d). Evaluasi Alat}

Pada metode ini bertujuan untuk mengetahui kelebihan dan kekurangan dari perangkat ini, sehingga kita dapat menyimpulkan kondisi dan kualitas dari alat ini.

\section{e). Penyusunan Laporan Akhir Penelitian}

Pada tahap ini telah sampai pada penerapannya kemudian kami mendokumentasikan dan menyusunnya dalam sebuah laporan akhir penelitian, serta data - data yang nantinya dapat digunakan sebagai pengukur tingkat keberhasilan alat yang telah dibuat.

\section{Hasil dan Pembahasan}

Pada bagian hasil dan pembahasan akan diuraikan tentang pengujian berdasarkan perancangan dari sistem yang telah dibuat. Pengujian ini dilakukan untuk mengetahui kemampuan dari sistem dan untuk mengetahui apakah sistem sudah berjalan dengan perencanaan, sekaligus mengetahui kelebihan dan kekurangan sistem yang dirancang.

\subsection{Spesifikasi}

Adapun spesifikasi dari Arduino Uno adalah sebagai berikut:

1. Chip mikrokontroler : ATmega 328P

2. Tegangan operasi : $5 \mathrm{~V}$

Tegangan input yang direkomendasikan

3. via jack DC : $7 \mathrm{~V}-12 \mathrm{~V}$

4. Tegangan input batas via jack DC : 6V-20V

5. Pin digital I/O : 14 buah, 6 buah adalah PWM

6. Pin analog input : 6 buah

7. Arus DC tiap pin $\mathrm{I} / \mathrm{O}: 40 \mathrm{~mA}$

8. Arus DC pin $3.3 \mathrm{v}: 50 \mathrm{~mA} 26$

9. Memori flash : $32 \mathrm{~kb}$, sebagai boot loader sebesar $0,5 \mathrm{~kb}$

10. SRAM : $2 \mathrm{~kb}$

11. EEPROM : $1 \mathrm{~kb}$

12. Clock speed : $16 \mathrm{Mhz}$

13. Dimensi : $68,6 \mathrm{~mm} \times 53,4 \mathrm{~mm}$

14. Berat : 25 gram

Contoh rangkaian Arduino Uno dapat dilihat pada gambar 6.

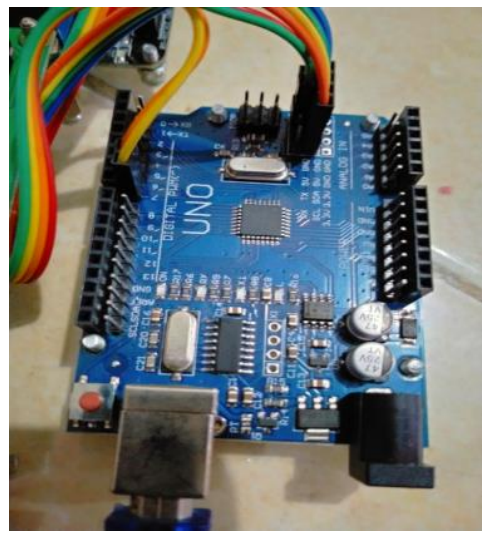

Gambar 6. Rangkaian Arduino Uno Mikrokontroler

Pada Gambar 6 terlihat bahwa sistem minimum Arduino Uno terhubung dengan bagian-bagian yang lain seperti LCD 16x2, sensor salinitas, relay. Pada sistem minimum Arduino Uno, terdapat lampu indikator yang difungsikan untuk mengetahui apakah rangkaian sedang bekerja atau tidak.

\subsection{Rangkaian Sensor Konduktivitas}

Rangkaian sensor konduktivitas pada alat ini berfungsi sebagai pendeteksi kadar garam air dengan Arduino Uno.

1. Adapun spesifikasi dari sensor konduktivitas adalah sebagai berikut:

DOI: $\mathrm{xxxx}$

Lisensi: Creative Commons Attribution 4.0 International (CC BY 4.0) 
2. Bekerja pada tegangan DC 5V

3. Support arduino dan mikrokontroler lainnya

4. Memiliki sensitivitas pada bahan yang bersifat konduktif

5. Kedalaman cairan pada saat pengukuran sebesar 5,5 $\mathrm{cm}$ dari ujung sensor

Contoh rangkain sensor konduktivitas dapat dilihat pada gambar 7

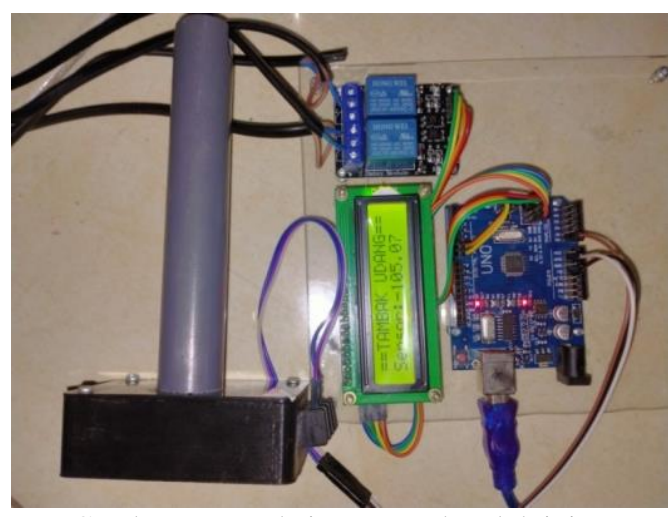

Gambar 7. Rangkaian sensor konduktivitas

\subsection{Rangkaian Keseluruhan}

Rangkaian keseluruhan sistem ini merupakan gabungan dari rangkaian-rangkaian yang telah dibahas sebelumnya seperti LCD, Sensor Konduktivitas, Relay dan pompa air. Rangkaian keseluruhan dapat dilihat pada gambar $8,9,10$

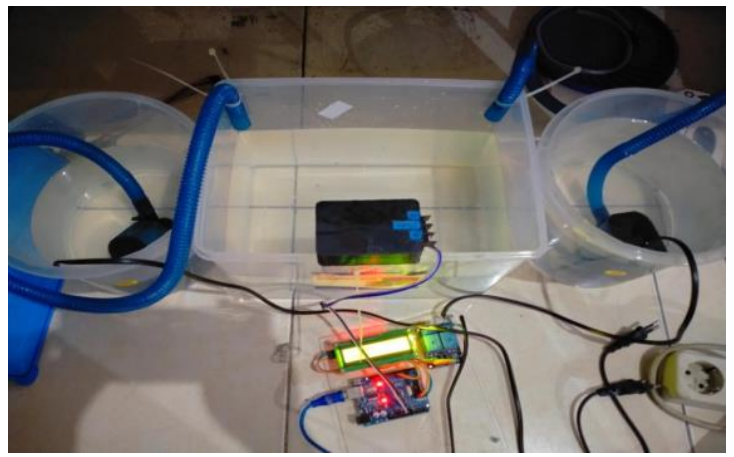

Gambar 8 Rangkaian tampak dari atas

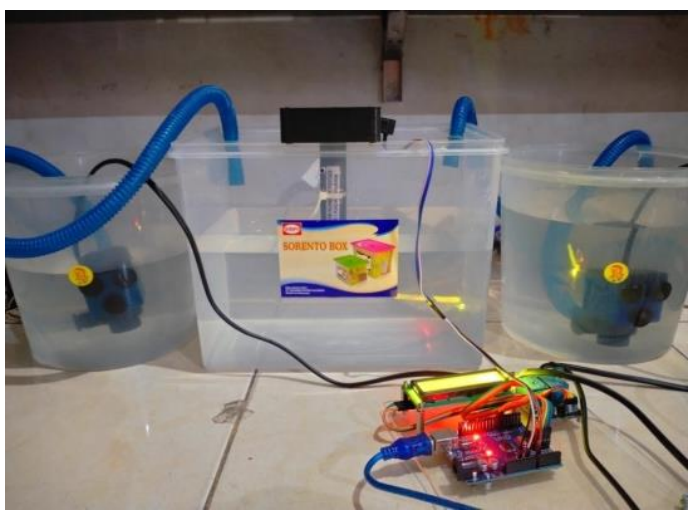

Gambar 9. Rangkaian tampak dari samping

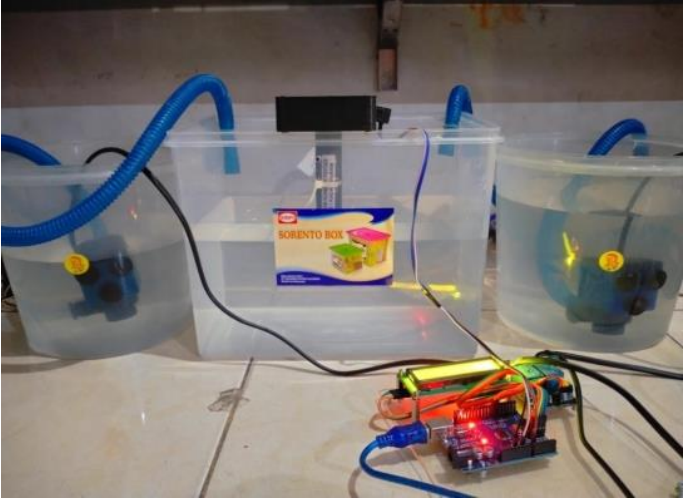

Gambar 10. Rangkaian tampak dari samping

\subsection{Pengujian Sensor Konduktivitas dengan LCD}

Pengujian dilakukan untuk mengetahui fungsi dan kinerja dari keseluruhan sistem. Program pengujian disimulasikan di suatu sistem yang sesuai. Pengujian ini dilaksanakan untuk mengetahui kehandalan dari sistem dan untuk mengetahui apakah sudah sesuai dengan perencanaan atau belum. Pengujian pertamatama dilakukan secara terpisah, dan kemudian dilakukan kedalam sistem yang telah terintegrasi.

Rangkaian LCD pada penelitian ini berfungsi untuk menampilkan informasi berupa tulisan dan data nilai sensor yang dibaca oleh Arduino Uno. Untuk mengetahui apakah rangkaian LCD dan Sensor Konduktivitas yang telah dibuat dapat bekerja sesuai yang diinginkan maka dilakukan pengujian Sensor Konduktivitas dan rangkaian LCD yang dihubungkan dengan minimum sistem Arduino Uno.

Peralatan yang dibutuhkan untuk melakukan pengujian ini yaitu :

1. Minimum Sistem Arduino Uno.

2. Kabel data Arduino Uno.

3. Rangkaian Sensor Konduktivitas

4. Rangkaian LCD $16 \times 2$.

5. Software Arduino IDE.

Blok diagram pengujian rangkaian LCD dengan Arduino. Lihat Gambar 11.

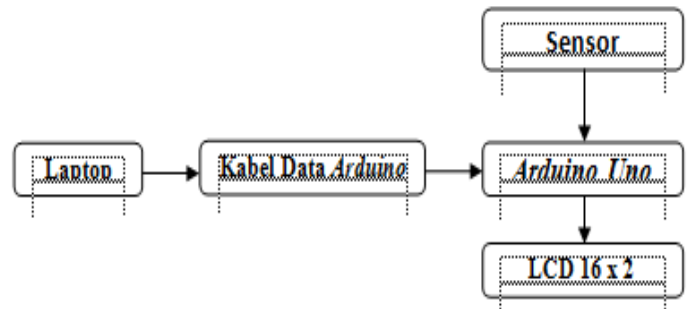

Gambar 11. Blok Diagram Pengujian Sensor Konduktivitas dengan LCD

DOI: $\mathrm{xxxx}$

Lisensi: Creative Commons Attribution 4.0 International (CC BY 4.0) 
Langkah-langkah melakukan pengujian rangkaian Kemudian“lcd.backlight(); lcd.init();”berfungsi untuk sensor Konduktivitas dan LCD : inisialisasi awal bahwasanya LCD mulai digunakan

\section{Buka aplikasi Arduino IDE}

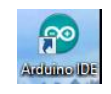

\section{Kesimpulan}

2. Selanjutnya akan muncul tampilan awal Setelah dilakukan perancangan, pembuatan dan "sketch_xxxxxx" secara otomatis seperti pada pengujian terhadap prototype stabilitas kadar air langkah sebelumnya. garam maka diperoleh beberapa kesimpulan yaitu : prototype stabilitas kadar air garam tersebut dapat

3. Mengetikkan listing program untuk pengujian mengukur tingkat kadar garam (salinitas) suatu larutan rangkaian LCD seperti pada gambar 12

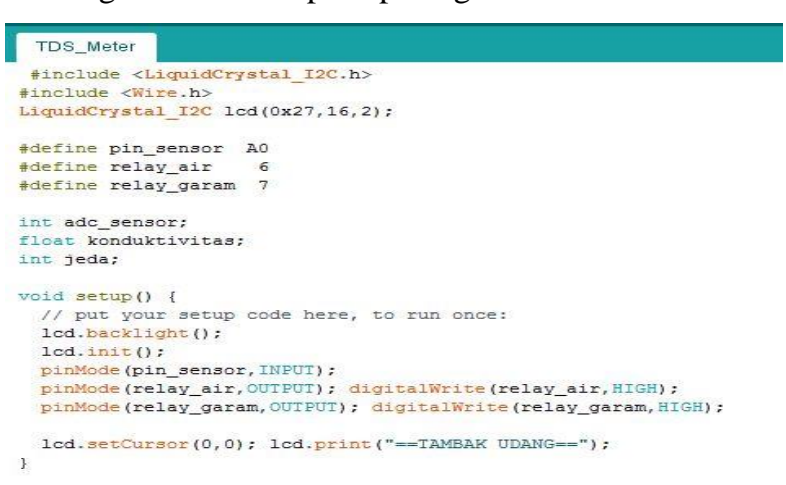

Gambar 12. Listing Program Pengujian LCD

\subsection{Analisa Hasil Program :}

Pada uji coba rangkaian Arduino Uno terhubung dengan LCD, diperlukan pemanggilan library \#include $<$ LiquidCrystal_I2C.h $>$ dan juga "Liquid Crystallcd(0x3F,16,2);,"- adalah listing program untuk pengaturan alamat LCD dan ukuran LCD jumlah baris dan kolom sesuai LCD yang digunakan. Yang berfungsi untuk menambahkan fungsi-fungsi program menampilkan karakter pada LCD. berdasarkan konduktivitasnya sehingga harapannya bisa diimplementasikan ke dalam alat yang sesungguhnya sehingga bisa mencegah tingkat kematian udang.

\section{Referensi}

[1] E. Salfia, M. Kamal, I. Pendahuluan, dan A. Salinitas, "Rancang Bangun Alat Pengendalian Dan Monitoring Kualitas Air Tambak Udang Berbasis Salinitas Dan Kadar Oksigen Terlarut," $J$. Tektro, vol. 2, no. 2, hal. 24-29, 2018.

[2] N. Ramadhana, A. W. Purwandi, dan R. Saptono, "Rancang bangun sistem monitoring konsentrasi kadar garam pada tambak ikan bandeng menggunakan android," Semant. Sch., 2019.

[3] D. N. Ratna, T. W. Tri, dan D. Listiana, Perkembangan budidaya tambak udang di pesisir Tuban 1980-2015. Yogyakarta: Balai Pelestarian Nilai Budaya (BPNB), 2018.

[4] Jamaludin, Muhammad Khoiruddin Harahap dan Evan Afri, "Penggunaan Albanto ( Alat Bandeng Presto ) untuk Meningkatkan Nilai Olahan Ikan Bandeng desa Batang Kilat Medan," TRIDARMA Pengabdi. Kpd. Masy., vol. 3, no. 1, hal. 136-142, 2020.

[5] M. C. Bahari, S. Hutabarat, P. Studi, M. Sumberdaya, J. Perikanan, dan U. Diponegoro, "Pengaruh suhu dan salinitas terhadap penetasan kista artemia salina skala laboratorium," vol. 3, hal. 188-194, 2014.

[6] J. Jamaludin dan R. Romindo, "Sistem Informasi Akademik Berbasis Web Menggunakan Metode Waterfall Pada SMA Kemala Bhayangkari I Medan," in Semantika, 2019, hal. 17-27.

DOI: $\mathrm{xxxx}$

Lisensi: Creative Commons Attribution 4.0 International (CC BY 4.0) 